\title{
7. THE LITHOLOGY AND GENESIS OF THE SEDIMENTARY DEPOSITS IN THE NORWEGIAN BASIN AND WESTERN PART OF THE LOFOTEN BASIN
}

\author{
A.G. Kossovskaya, P.P. Timofeev, and V.D. Shutov, \\ Geological Institute of the Academy of Sciences, USSR
}

\section{INTRODUCTION}

Sedimentary deposits recovered from Sites 336, 337, 345,346 , and 350 drilled in the Norwegian and Lofoten basins are clearly subdivided into three major complexes reflecting the stages in the historical evolution of this region (Figure 1).

1) The lower Eocene-Oligocene complex is generally composed of clastic sediments/rocks representing terrigenous material and components derived from synchronous volcanic activity. The latter are largely of a basaltic nature.

2) The middle-upper Oligocene-Miocene complex is characterized by a relatively smaller influx of clastic material, and widespread development of biogenic siliceous sediments. These indicate a maximum of pelagic sedimentation.

3) The upper complex, formed mostly of clastic sediments, is associated with a complicated cyclic history of glacial-marine sedimentation.

\section{STAGE 1-EOCENE-OLIGOCENE}

The clastic associations of the sediments/rocks during the initial stages of sedimentation in the Eocene and the Oligocene are diverse and complex. This is attributed to different structural-paleogeographical environments in the various sectors of the Norwegian and the Lofoten basins.

In the western part of the Lofoten Basin (Site 345), a basalt breccia is overlain by very poorly sorted pebbly mudstones with "exotic" pebbles of granites, quartz, and limestones from a typical platform association. These rocks are characteristic of slump deposits. The slump deposits are covered by turbidites whose appearance reflects a deepening of the basin, and an increase in the development of turbidity currents. Upper layers of the turbidite sequence were also found at Site 346. However, the site did not penetrate basalts or slump deposits. A turbidite deposit was also cored at Site 350. Here slump deposits are absent, and the turbidites immediately overlie basalts.

Site 336 was located on the northern slope of the Iceland-Faeroe Ridge. At the base of the hole, alkaline basalts are present which are extensively decomposed in their upper portions due to (subaerial?) weathering and subsequent hydrothermal reworking. The initiation of this sedimentary series seems to be associated with the subsidence of the Iceland-Faeroe Ridge in the middle Eocene (?). The sedimentary layers are composed of coarse volcanogenic rock fragments within a matrix of basalt disintegration products. These deposits grade upwards into finer sediments, first silty and then clayey, composed of reworked hyaloclastics. This sedimentary series is also present in Hole 350, however, in Hole 350 there is a greater dilution by terrigenous material.

Further north in the Norwegian Basin, along the eastern slopes of the Jan-Mayen Ridge, terrigenous components become more pronounced. Deposits of Eocene-Oligocene age at Site 346 are exclusively terrigenous, with subordinate volcanic components.

The upper (?) Eocene-Oligocene, in both the Norwegian and Lofoten basins, was a time when a thick series of clastic pebbly mudstones and rare sands accumulated. The sediments contain varying proportions of volcanogenic and terrigenous components. These deposits contain bioturbation textures (Zoophycos). These are known to be characteristic of shallow-water environments, and, less frequently, of middle-deep basins (Bradley, 1973). In several layers, the deposits contain numerous remnants of vegetable detritus. It appears that sedimentary intervals enriched in carbonized detritus may serve as an indicator of a maximum shallowing and/or proximity of land. Pyritization is strongly developed throughout the entire series, a sign that reducing conditions existed nearly continually.

The terrigenous component is most completely and graphically represented at Site 346 (Figure 1). Here, the entire Eocene-Oligocene section is composed of homogeneous, massive, poorly sorted siltstones containing scattered quartz pebbles. Clastic material forming the siltstones includes a feldspar-quartz association with abundant biotite fragments redeposited from the platform. with abundant biotite fragments. Since the quartz grains have regeneration rims and were derived from metamorphic schists and ancient granitoid complexes (Simanovich, 1975), it is indicated that the clastic material was derived from a shield association.

The matrix is almost entirely made up of products from the decay of trioctahedral micas. The transitional chlorite phase was distinctly observed. Genetically, the disintegration products of biotite micas are generally associated with the alteration of ancient quartz-biotite schists and gneisses of Greenland. However, a volcaniclastic or volcanogenic origin for a part of biotite (phlogopite) is probable. The biotite is present in the Tertiary alkaline lavas of the Jan-Mayen Ridge (Flower, 1969) and in alkaline basalts cored at a number of Leg 38 sites.

Biotite transformation, commonly following the biotite-chlorite-vermiculite-montmorillonite transformation pattern is specific and compares with this series of alteration observed on continents (Walker, 1949; 
Sea Leve1

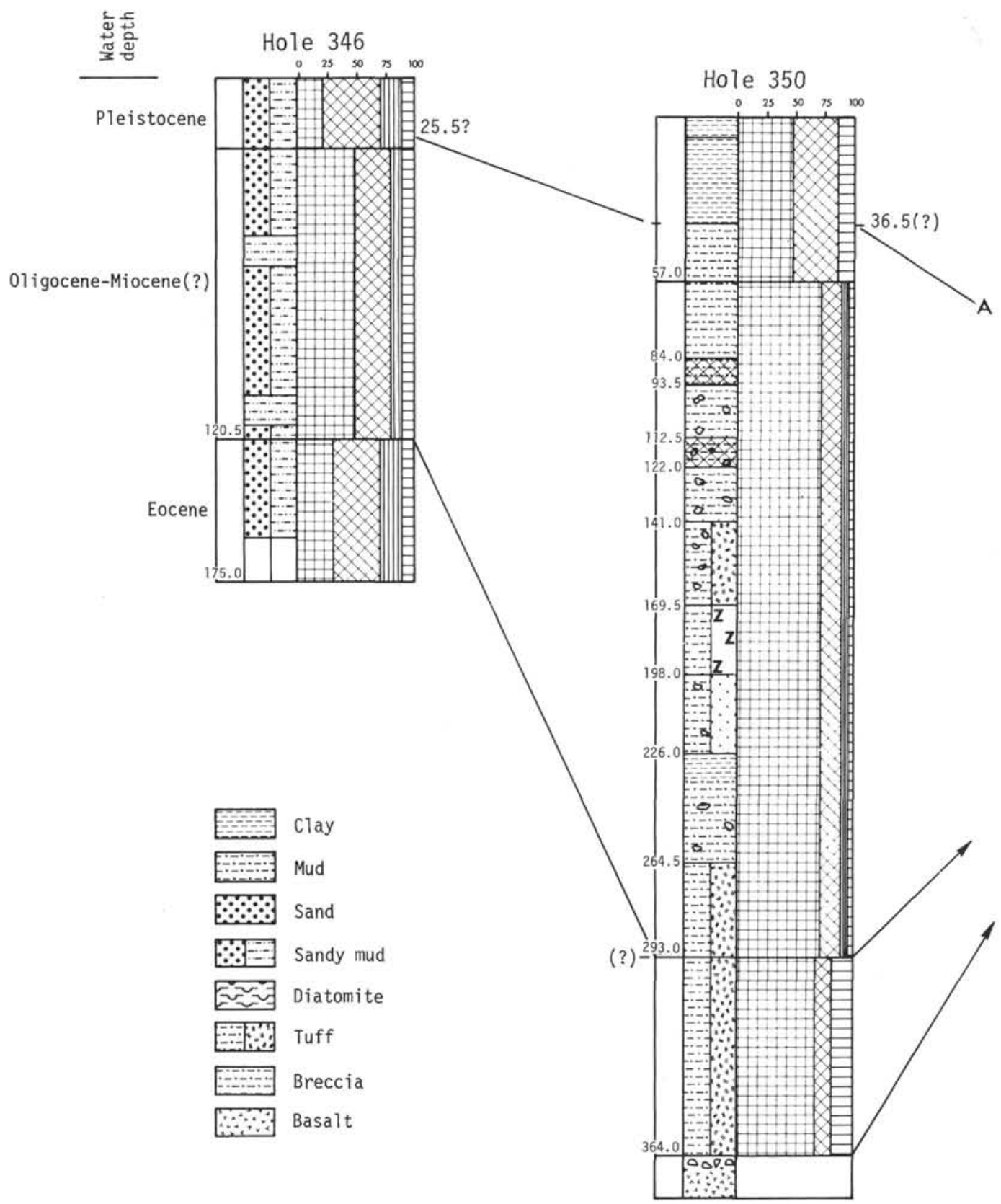

Figure 1. Lithologic columns of Sites 346, 350, 337, and 336.

Kossovskaya et al., 1963). Its peculiarity is the preservation of a high $\mathrm{K}_{2} \mathrm{O}$ content in the layer silicate structure. This could only occur in seawater. During continental weathering, potassium is one of the first elements to be removed from the biotite lattice. Table 1 presents a comparative description of biotites from alteration during continental weathering (I), clays formed from transformation of biotite in continental basins (II), biotite matrix from Site 346 (III), and phlogopite from alkaline basalts of the Jan-Mayen Ridge (IV). Comparison of the data in Table 1 suggests two conclusions: (1) a high iron content in the biotite matrix material connecting quartz grains is a sign of an increased iron content of the primary biotites, whereas in the alkaline basalts of the Jan-Mayen Ridge, the biotites belong to the phlogopite series with a low iron and higher magnesium content; (2) a high $\mathrm{K}_{2} \mathrm{O}$ content in the matrix is an indication that the main transformation of the biotite took place in the marine environment, not on the continent.

Site 346 clearly shows the nature of the clastic material and this is particularly evident in the graywackes of the lower part of the Oligocene series. Associations of the clastic quartz grains are identical to that association at Site 345 . However, in the matrix, the biotite component has been reduced to a minimum and 


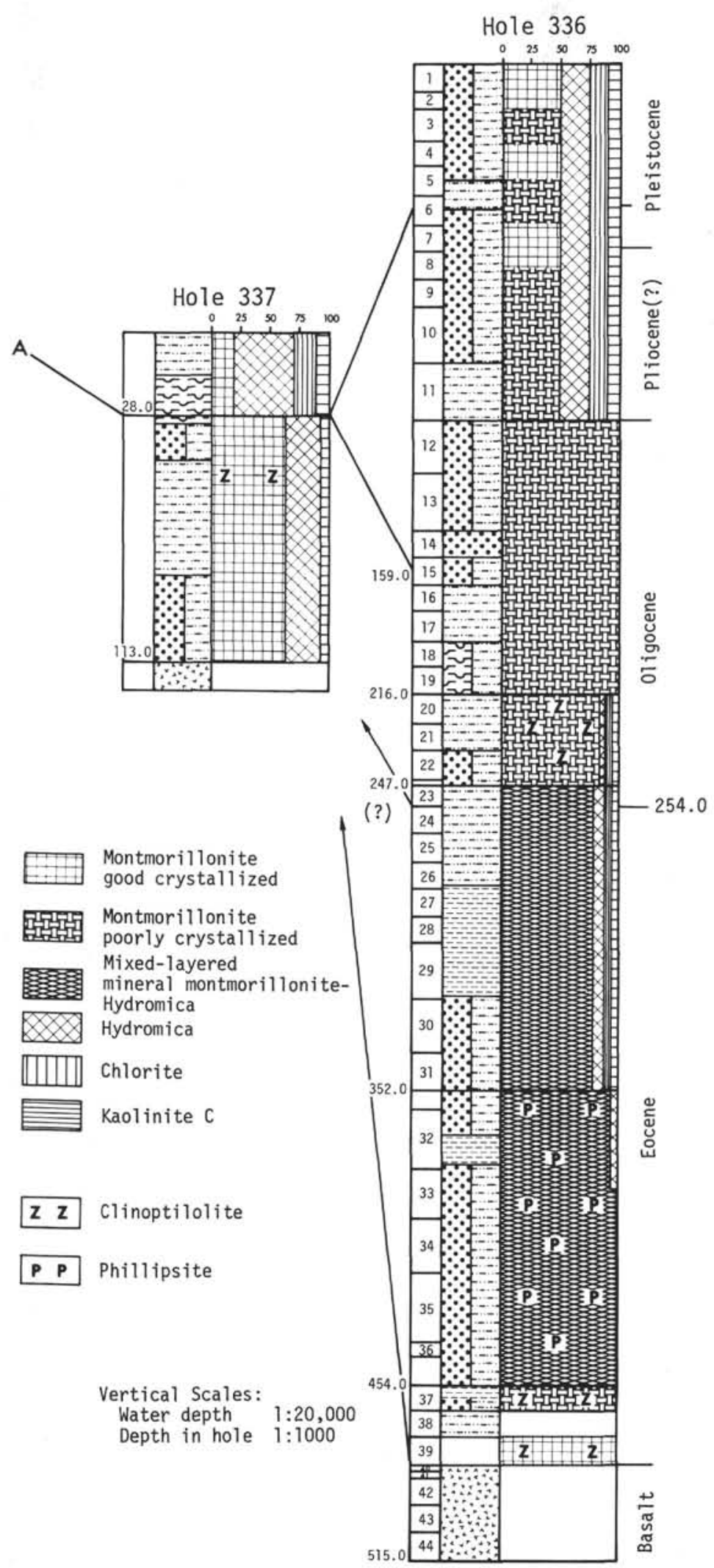

Figure 1. (Continued). 
TABLE 1

Comparative Characteristics of the Chemistry of Biotite Disintegration Products in Continental and Marine Environments

\begin{tabular}{|c|c|c|c|c|c|c|c|}
\hline \multirow[b]{3}{*}{ Components } & \multicolumn{4}{|c|}{ I } & \multirow[b]{3}{*}{ II } & \multirow[b]{3}{*}{ III } & \multirow[b]{3}{*}{ IV } \\
\hline & \multicolumn{2}{|c|}{$\begin{array}{c}\begin{array}{c}\text { Stages } \\
\text { (after }\end{array} \\
\text { Walker, 1949) }\end{array}$} & \multicolumn{2}{|c|}{$\begin{array}{c}\text { Stages } \\
\text { (after Kossowskaya } \\
\text { et al., 1963) }\end{array}$} & & & \\
\hline & I & II & I & II & & & \\
\hline $\mathrm{SiO}_{2}$ & 34.97 & 38.13 & 28.93 & 28.15 & 42.60 & 44.87 & 40.10 \\
\hline $\mathrm{TiO}_{2}$ & 5.64 & 4.79 & 1.33 & 0.75 & 1.60 & 1.40 & 6.15 \\
\hline $\mathrm{Al}_{2} \mathrm{O}_{3}$ & 15.30 & 15.88 & 19.05 & 17.51 & 19.02 & 21.58 & 12.02 \\
\hline $\mathrm{Fe}_{2} \mathrm{O}_{3}$ & 2.81 & 18.88 & 3.51 & 13.67 & 6.27 & 5.60 & 0.63 \\
\hline $\mathrm{FeO}$ & 21.23 & 2.99 & 20.19 & 9.22 & 7.79 & 3.74 & 8.84 \\
\hline $\mathrm{CaO}$ & 1.09 & 1.22 & 1.31 & 0.39 & 0.72 & 0.83 & - \\
\hline $\mathrm{MgO}$ & 8.83 & 4.92 & 11.44 & 10.55 & 7.40 & 2.88 & 17.40 \\
\hline $\mathrm{MnO}$ & & & & & 0.04 & 0.04 & 0.82 \\
\hline $\mathrm{Na}_{2} \mathrm{O}$ & 0.27 & 0.46 & 0.18 & 0.17 & 1.35 & 1.49 & 1.00 \\
\hline $\mathrm{K}_{2} \mathrm{O}$ & 7.17 & 3.66 & 3.30 & 1.46 & 1.37 & 5.03 & 8.36 \\
\hline $\mathrm{H}_{2} \mathrm{O}^{+}$ & 3.03 & 6.70 & $1076^{a}$ & 11.81 & 7.44 & 6.75 & 370 \\
\hline $\mathrm{H}_{2} \mathrm{O}^{-}$ & 0.31 & 2.38 & $10.10^{-}$ & 4.39 & 4.76 & 3.83 & 3.10 \\
\hline $\mathrm{CO}_{2}$ & & & & & HET & 0.27 & \\
\hline $\mathrm{C}$ & & & & & 0.47 & 0.64 & \\
\hline $\mathrm{P}_{2} \mathrm{O}_{3}$ & & & & & & 0.08 & \\
\hline$\Sigma$ & 100.55 & 100.01 & 100.00 & 98.07 & 100.93 & 99.04 & 99.02 \\
\hline
\end{tabular}

${ }^{\mathrm{a}} \mathrm{H}_{2} \mathrm{O}$ was not determined by difference from $100 \%$.

Note: I. Stages of the extensive alteration of biotite plates (continental); II. Clays (Lower Cretaceous of Yakutia) formed from biotite alteration in continental basins; average for 7 analyses; III. Clay matrix (after biotite) in marine sedimentary deposits of the Oligocene; Site 346, DSDP Leg 38; average for 6 analyses; IV. Biotite (phlogopite) from alkaline basalts of the Jan-Mayen Ridge.

is present only in some thin layers. A volcanogenic lowiron bentonite-like montmorillonite predominates. This type of volcanogenic montmorillonite is remarkably different crystallochemically from the volcanogenic ferrimontmorillonites associated with pelagic deposits. The same type of ferrimontmorillonite is the main mineral in the deposits of Holes 336 and 350 .

The montmorillonite from Hole 345 can be described as "medium" montmorillonite, very similar to ordinary bentonites. Its chief feature is a predominantly aluminum low-iron composition, which accounts for its resistance to acid treatment (heating in $\mathrm{HCl}$ ). Usual, pelagic ferrimontmorillonites readily dissolved in acids. It appears that the crystallochemistry of smectites can provide important information on the nature of the host rock. The authors have recently concluded that the homogeneity of pelagic "red" clays (whose basic component is ferrimontmorillonite) is attributable to the homogeneity of the composition of tholeiitic basalts. The products of a halmyrolytic decomposition of basalt hyaloclastics serve as the material for the formation of pelagic clays, Kossovskaya et al., 1975.

One can assume with certainty that during the Oligocene, volcanism with effusive products of a trachyandesitic composition was significant in the vicinity of Site 345 . It was from the trachyandesite volcaniclastics that the low-iron bentonite-like montmorillonites formed. These are best developed in the lower subseries, although they are a component of clays throughout the section. The chemical composition of rocks (Table 2) as well as the petrography of the relatively slightly montmorillonitized volcanic glasses (in which bipyramidal or irregularly eroded quartz grains and/or larger biotite plates are present) corroborate the above conclusion. The alternating presence of bentonite-like montmorillonites with ferrimontmorillonites in the sedimentary deposits, with the latter having been formed from true tholeiitic basalts, is witness to a diversity and differentiation over time of the character of volcanism, and of the composition of volcanic products supplied to the basin.

At Site 350 , terrigenous material abruptly declines and basaltic hyaloclastics dominate. This is even more apparent at Site 336, where ferrimontmorillonites are significant and often are accompanied by phillipsite. Both minerals represent halmyrolytic decay products of oceanic basalts. Large quantities of phillipsite suggest that the basalt volcanism was alkaline. The high iron content of ferrimontmorillonite gives credence to the supposition that the ferrimontmorillonite sediments were formed in conditions of an additional supply of iron. This supply is associated with exhalations and hydrothermal solutions.

The structural setting of the site near the axis of the lower Eocene rift zone on the Iceland-Faeroe Ridge is reflected in the sediments, and especially, clay minerals, which differ from those in all other sites in the Norwegian and Lofoten basins. It is well known that a high iron and manganese content is a usual feature of active spreading zones. 
TABLE 2

A Comparative Characterization of the Composition of Igneous Rocks, Their Decay Products, and Clays in Oceans

\begin{tabular}{|c|c|c|c|c|c|c|c|c|c|}
\hline \multirow[b]{2}{*}{ Oxides } & \multirow[b]{2}{*}{1} & \multicolumn{2}{|r|}{2} & \multirow[b]{2}{*}{3} & \multirow[b]{2}{*}{4} & \multicolumn{2}{|c|}{5} & \multicolumn{2}{|c|}{6} \\
\hline & & a & b & & & a & b & a & b \\
\hline $\mathrm{SiO}_{2}$ & 49.3 & 47.11 & 44.68 & 50.70 & 43.27 & 55.72 & 54.96 & 56.3 & 46.23 \\
\hline $\mathrm{TiO}_{2}$ & 1.5 & 1.55 & 1.92 & 0.79 & 1.24 & 0.68 & 0.65 & 1.8 & 3.45 \\
\hline $\mathrm{Al}_{2} \mathrm{O}_{3}$ & 17.0 & 18.37 & 18.76 & 19.35 & 16.20 & 15.67 & 15.90 & 17.8 & 16.85 \\
\hline $\mathrm{Fe}_{2} \mathrm{O}_{3}$ & 2.3 & 8.74 & 14.73 & 7.48 & 8.55 & 4.21 & 3.84 & 2.9 & 3.44 \\
\hline $\mathrm{FeO}$ & 6.8 & 0.16 & & 0.77 & 0.39 & 0.47 & 0.81 & 4.7 & 7.37 \\
\hline $\mathrm{CaO}$ & 11.7 & 2.34 & 0.42 & 0.80 & 1.38 & 2.17 & 1.82 & 4.7 & 10.75 \\
\hline $\mathrm{MgO}$ & 7.2 & 1.84 & 2.34 & 2.49 & 3.74 & 2.42 & 2.36 & 2.3 & 5.54 \\
\hline $\mathrm{MnO}$ & 0.2 & 0.14 & $\begin{array}{c}\text { not } \\
\text { determined }\end{array}$ & 0.08 & 0.13 & 0.15 & 0.12 & - & 0.38 \\
\hline $\mathrm{Na}_{2} \mathrm{O}$ & 2.7 & 2.41 & 1.45 & 0.34 & 3.83 & 1.84 & 2.18 & 4.8 & 2.78 \\
\hline $\mathrm{K}_{2} \mathrm{O}$ & 0.2 & 3.48 & 3.66 & 2.38 & 2.21 & 1.56 & 1.46 & 4.7 & 2.43 \\
\hline $\mathrm{H}_{2} \mathrm{O}^{+}$ & 1.3 & 8.52 & $\begin{array}{c}\text { not } \\
\text { determined }\end{array}$ & 7.04 & 5.02 & 4.21 & 4.62 & - & 0.13 \\
\hline $\mathrm{H}_{2} \mathrm{O}^{-}$ & & 5.20 & & 6.45 & 8.86 & 9.54 & 10.17 & - & 0.22 \\
\hline $\mathrm{P}_{2} \mathrm{O}_{5}$ & HET & 0.22 & 0.03 & 0.20 & 0.12 & 0.05 & 0.04 & - & 0.62 \\
\hline$\Sigma$ & 99.9 & 100.8 & & 99.91 & & & & 100.0 & \\
\hline
\end{tabular}

Note: 1. Average composition of oceanic basalts (Engel and Havens, 1965); 2. (a) composition of disintegration products of the basalts of the Swallow bank; the most extensively altered rock (Matthews, 1971); (b) palagonite of basalts from sites of DSDP Legs 3, 5, 22 (Melson, 1973); 3. Kossovskaya et al., 1975;4. Fe-montmorillonite clays from Site 337, DSDP Leg 38 (average for 3 samples); 5. Composition of bentonite-like Al-montmorillonite clays (a) and interstratified glass layers (b) from Site 345 DSDP Leg 38; 6. Alkaline basalts of Mid-Atlantic Ridge: (a) lavas of a trachyte-like composition (average for 2 analyses, recalculated for sum without water); (b) average for 2 analyses of basalt of Jan-Mayen Ridge.

\section{STAGE 2-OLIGOCENE-MIOCENE}

A characteristic feature of this sedimentation stage is a leveling of the sedimentation environments. This is associated with deepening basins and with true pelagic sediments being deposited in the central portions. Towards the end of the stage the basin becomes deeper. Thus terrigenous material is found only at the borders of the basin (Sites 336, 346). Siliceous biogenic and biogenic-clay deposits accumulate in the deeper areas along with fine, reworked volcaniclastics. The volcaniclastics are a basic basalt, which is indicated both by petrographic (volcanic glasses composition with $n=1.610-1.605$ ) and chemical data (see Table 2, Site 337 ), and by the crystallochemical characteristics of the smectite minerals belonging to the typical pelagic ferrimontmorillonites. At Sites 337, 350, and 336 ferrimontmorillonite is the predominant clay component, present either as a well-crystallized form (usually combined with mixed-layer illite-montmorillonite units) or as a poorly crystallized form due to absorption of $\mathrm{SiO}_{2}$. At Hole 345, a more acid and alkaline character of volcaniclastics is apparent (volcanic glasses with $d=$ 1.53-1.55), which is manifested by alternating bentonite-like Al-Fe-montmorillonites (see Table 2, Site 345) and true ferrimontmorillonites. This phenomenon is also observed at Site 336, but Al-Femontmorillonites are a subordinate component.

In the peripheral, shallow sectors of the basin, the formation of biogenic-siliceous sediments is accompanied by an intensive glauconite formation. It should be noted that the glauconite is very undeveloped and appears as a series of mixed-layer units ranging from true montmorillonite through montmorillonite-mica layers to true glauconite. Similar to glauconites investigated earlier (Shutov et al., 1972), the glauconites with "open structure" present in Miocene sediments were formed from transformation or iron montmorillonites which sorbed potassium cations from seawater.

Throughout the entire Oligocene-Miocene stage of development, an exhalatory-hydrothermal activity was taking place. This was expressed in sporadic and local occurrences of iron-manganese mineralization, probably accompanied by concentrated zeolite formation.

\section{STAGE 3-PLIO-PLEISTOCENE}

Pleistocene sediments at Sites 336, 337, 345, and 350 were formed under the strong influence of a supply of glacial material via ice-rafting.

The abundance of transported glacial terrigenous material is linked with a fluctuation of the ice front. The position of this front and its variation, i.e., its advance or retreat, is dependent on the climate of the Arctic areas of Eurasia. These areas become warmer because of the penetration of warm Atlantic waters into the Norwegian basin (Udintsev, 1975). This warming was marked by formation of marlstones with more reworked, dispersed clay material. Thus, these events affected the lithologic composition, thickness, and distribution of the Pleistocene sediments. The maximum 
thickness is indicated at Site $336(\cong 159 \mathrm{~m}$ ?) on the Iceland-Faeroe Ridge. Generally, the Pleistocene sediment thicknesses have no direct correlation with bathymetry, as should be expected of an ice transport product. For example, Sites 337 and 345 near the 3000meter isobath have Pliocene to Pleistocene thicknesses of 47 and 36.5 meters, respectively. Similarly, Sites 346 and 350 , near the 2000-meter isobath, have thicknesses of 25.5 and $36.5(?)$ meters, respectively.

The Pleistocene sediments at all sites are composed of unsorted sand-silt-clay (more rarely, pelitomorphous clays) with fragments of granites, basalts, biotite and amphibole schists, and limestones.

The clay component in the Pleistocene sediments also largely derived by ice transport is polycomponent and polygenetic. A large proportion of hydromicas (up to $60 \%$ ) in the form of muscovites and biotites and also chlorites (up to 30\%) have been derived from land. Montmorillonites containing aluminum or iron were formed from altered volcanogenic material. The peculiar K-montmorillonites and mixed-layer minerals, such as vermiculite-montmorillonite, formed from which the transformation of metastable trioctahedral micas might have taken place on the continent after deposition from the ice, during ice-rafting, or by diagenesis after final deposition. Spatial variations in the material clay composition are also observed. For example, in the Pleistocene sediments at Site 346, which is nearer to Greenland, there is an abundance of chlorite and mixed-layer products from the alteration of biotite schists. At Site 350, nearer to Iceland, and at Site 336 , on the Iceland-Faeroe Ridge, there is a noticeable increase in montmorillonitized volcanic products. In the Pleistocene sediments of Sites 337 and 345 , fine-dispersed K-montmorillonitic minerals are more widespread. Therefore, along with the ice transport, the proximity to the areas of supply is also important.

\section{REFERENCES}

Bradley, J., 1973. Zoophycos and Umbella: Their synthesis and identification: Paleogeogr. Paleoclimat. Paleoecol., v. 13.

Flower, M.F., 1969. Phlogopites from Jan-Mayen Islands (North Atlantic): Earth Planet. Sci. Lett., v. 6, p. 461-466.

Engel, A.E.G. and Havens, R.Z., 1965. Chemical characteristics of oceanic basalts and the upper mantle: Geol. Soc. Am. Bull., v. 76, p. 5.

Kossovskaya, A.G., Drits, V.A., and Alexandrova, V.A., 1963. On trioctahedral micas in sedimentary rocks: Intern. Clay Conf. Proc., Stockholm (Pergamon Press), p. 147169.

Kossovskaya, A.G., Gushchina, E.B., Drits, V.A., Dmitrik, A.L., Lomova, O.S., and Serebryannikova, N.A., 1975. Mineralogy of Mesocenozoic deposits of the Atlantic Ocean (according to the materials of Leg 2 of Glomar Challenger): Litologiya i poleznye iskopaemye, no. 6 , p. 12-35.

Matthews, D.H., 1971. Weathered basalts from Swallow Bank, an abyssal hill in the NE Atlantic: Phil. Trans. Roy. Soc. London, p. 515-571.

Melson, W.G., 1973. Basaltic glasses from DSDP. Chemical characteristics, composition of alteration products and fission track "ages": Am. Geophys. Union Trans., v. 54, p. 1011-1014.

Shutov, V.D., Katz, M.Ya., Drits, V.A., Sokolova, A.L., and Kazakov, G.A., 1972. Crystallo-chemical heterogeneity of glauconite as depending on the conditions of its formation and postsedimentary changes: Intern. Clay Conf. Proc., Madrid, p. 269-280.

Simanovich, I.M., 1975. Quartz of arenaceous rocks: Synopsis of thesis, Genetic types and postsedimentary transformations, Moscow.

Udintsev, G.V., 1975. Leg 38 of Glomar Challenger: Priroda, v. 6 , p. $100-101$.

Walker, G.F., 1949. The decomposition of biotite in the soils: Am. Mineral., v. 28, p. 693-703. 